\title{
Method and Substance of Islamic Economics Revisited
}

\author{
Mohd Mahyudi \\ Assistant Professor, Kulliyyah of Economics and Management Sciences \\ International Islamic University Malaysia \\ Enizahura Abdul Aziz \\ Centre for the Study of Shari'ah, Law and Politics, Institute of Islamic \\ Understanding Malaysia (IKIM)
}

\begin{abstract}
This paper provides fresh deliberations on the method and substance of Islamic economics by relying on the structure and contents of Nienhaus (2013). Introspective arguments are furnished to soundly argue that Islamic economics is still a widely disregarded field; it is an integrated science; its normative dimension is not a deterrent element; 'Islamic economics light' studies are one inseparable part of the discipline; and Islamic economics is a political economy. On the aforementioned issues, we essentially make further elaborations on our Islamic economics definition, 'Qur'ānic framework', Islamic epistemology and Islamic criteria originating from our paper Mahyudi and Abdul Aziz (2017). The elaborations are extended to expound on their positive impact to the 'Islamization of Knowledge' agenda. We also utilize Bakar (2016) to reduce the observed tension between Sharīah scholars and Islamic economists that is triggered by issues surrounding legal form and economic reasoning of Islamic banking and finance products. Armed with the latest views over some foundational topics in the philosophy of Islamic economics science, our discussions proffer some guiding points on the proper conduct of Islamic economists in engaging with conventional economists and Islamic jurisprudence experts.
\end{abstract}

Keywords: Philosophy of Islamic economics, Islamic social science, Islamization of knowledge, Value-free economics.

JEL Classification: B41, B59, A12, A13

KAUJIE Classification: A0, G1, H11, H14 


\section{Introduction}

This article is a detailed attempt to provide some pertinent responses to the issues raised by Volker Nienhaus in his 2013 paper titled "Method and Substance of Islamic Economics: Moving Where?" (henceforth Nienhaus) as published in the Journal of King Abdulaziz University: Islamic Economics. In it, he tries to drive home some thought-provoking reflections on the intellectual endeavors undertaken under the banner of Islamic economics. The ability of Islamic economists to present ideas that display a new paradigm based on or at least consistent with the Islamic worldview is put under scrutiny. With regard to their use of quantitative approach, this similarity with mainstream economics seems to project a lack of holistic or systemic dimension to support a proper establishment of Islamic economics science. To Nienhaus, this bleak scenario is exacerbated by the continuous deficiency in the constructive engagement between the significant 'builders' of the discipline; namely the economists and Sharī'ah scholars. Thus, he argues that the direction of Islamic economics is objectively seen as one that moves closer to the conventional status quo especially when the development of this science is predominantly charted and filled up by Islamic finance, which is supposed to be a mere sub-field of Islamic economics.

We acknowledge that Nienhaus' paper has two main parts which are spread over six sections. By the first part, we mean those deliberations under sections 1 to 3 . The second part is from section 4 until 6 . We differentiate these parts based on the amount of focus given to the subject matter of his paper; that is the philosophy of Islamic economics. In the first part, Nienhaus lays down the general background of his discussion. This allows him to bring in some basic resemblance of Islamic economics with Christian economics and Max Weber's critique on such faithbased efforts in section 1 . Then, he dedicates section 2 to forcefully describe knowledge as 'belief beyond reasonable doubts' by putting forward the two concepts of belief; constative and prescriptive beliefs. To that end, Hume's epistemological stance on 'is' and 'ought' statements is well-utilized. Finally, he proclaims that "The Christian religion thus offers a 'complete code of life' and its doctrinal system embodies, inter alia, proposition for the economic life.
An academic discipline emerged that can be called 'Christian economics'" (p. 182). In section 3, he presents a historical view on the evolution of economics methodology from the classical rationalism and empiricism of the $18^{\text {th }}$ and $19^{\text {th }}$ century to value-free social science of the $20^{\text {th }}$ century and Feyerabend's methodological 'anything goes' of present times. Interestingly, this methodological pluralism opens the door for any science as long as it maintains a rational attitude irrespective of the worldview that the scientists adhere to. By the second part, we refer to those later sections wherein Nienhaus makes several analytical assessments on multiple points relating to the discipline of Islamic economics proper. Starting from pages 189 to 204, he fairly and justifiably highlights some serious problems with Islamic economics science, its proponents and its current 'ambassador'; Islamic finance. In a nutshell, Nienhaus' first part has far less direct reference to Islamic economics compared to the later sections of 4 until 6 .

While there are little talking points to be raised on Nienhaus' projection of the Christian paradigm and its minimal influence on conventional economics as appeared in the first part, there is a lot to be said on the second part of his paper when scrutinized from the Islamic perspective. However, section 6 is entirely about Islamic financial intermediation. He proposes to replace the existing Islamic banking model with institutions based on mutual funds investment portfolios; which he claims to be more in line with "the much cherished basic principles of Islamic finance in substance" (p. 204). Apparently, section 6 is actually a subtopic in Islamic finance. Since this paper is intended to limit its scope to cover the relevant reviews; and not proposal of this sort, shared by Nienhaus on the Islamizing economics efforts, we would skip his section 6 . Therefore, this paper seeks to simply focus on sections 4 and 5 of Nienhaus.

We are also aware about the existence of Aydin (2013) that serves as an initial response to Nienhaus. Aydin provides his commentaries on both part 1 and part 2 viz. the whole content of Nienhaus. Nonetheless, that huge task has inadvertently led to a rather cursory take on Nienhaus by Aydin. Thus, to improve this situation, focusing on sections 4 and 5 of Nienhaus (2013) acts as the motivation for this paper. 
This paper aims to provide fresh deliberations on the method and substance of Islamic economics by relying on the structure and contents of Nienhaus (2013). Throughout this paper, we capitalize on Mahyudi and Abdul Aziz's (2017) definition of Islamic economics and its ensuing 'Qur'ānic framework' to achieve this aim. Introspective arguments are furnished to properly accept Tahir's (2017) challenge for the observance of intellectual integrity in Islamic economics research. The next section covers our attempt to critically comment on the problems of Islamic economics as identified by Nienhaus. These problems arise primarily from this discipline's interaction with conventional economics over the span of four decades. In a way, our section 2 is to answer the question: "What is the relation between conventional economics and the religion of Islam?" as posed by Zarqa (2003, p. 4). In section 3, we seek to redress the unsettled relation between Islamic economics and fiqh (Islamic jurisprudence). This is our small contribution to respond to Zarqa's (2003, p. 4) question: "What is the relation between Islamic economics and Islamic jurisprudence?". Accordingly, we will scrutinize, evaluate and state our position on Nienhaus point by point based on the validity and soundness of his assessments and assertions. Section 4 concludes this paper.

\section{Some Problems of Islamic Economics: A Fresh Relook}

Methodological pluralism in economics methodology is a boon for heterodox schools of thought which includes Islamic economics. Here, we are with Siddiqui (2011) who avers that Islamic economics is certainly a part of the alternative projects within the house of economic science. So, in agreement with Nienhaus, what really matters now is for Islamic economics to be 'reasonable' in its pursuit to contribute towards the growth of the economics body of theories. To test out this 'reasonable' character, Nienhaus rightly identifies four problems or issues associated with the efforts of Islamizing economics thus far. The following subsections are our direct response to those four problems raised in section 4 of Nienhaus.

\subsection{Islamic Economics as a Widely Disregarded Field}

Nienhaus rightly asserts that the economists of the world have not been giving attention to the nascent discipline of Islamic economics; despite its increasing presence in terms of scholarly writings. He proves his point by showing the meagre number of research works that have been captured by the American Economic Association (AEA) and its electronic bibliography, EconLit; which includes non-AEA mainstream journals too.

On the above assertion of Nienhaus, this present paper takes the position to concur with that overall view of his. In addition to the four reasons provided by Nienhaus, we could add one more factor behind the lack of visibility of Islamic economics in the scholarly space, and that is the relatively low quantity and quality of Islamic journals. This additional reason comes from the findings of Arshad (2016). Interestingly, Arshad sets out to assess the quality of journals related to the discipline of Islamic Economics, including Islamic Business, Islamic Accounting, Islamic Management, and Islamic Banking and Finance. This broadening of the search terms clearly overstates the number of journals that are classified as related to Islamic economics. On the other hand, one of that study's limitation is the omission of journals published in languages other than English. From thereon, Arshad identifies 25 journals and evaluates them using nine assessment criteria; namely Impact Factor, Google Scholar Metrics, Eigenfactor Score and Article Influence Score, Publisher, Editorial Board, Acceptance/Rejection Rates, Peerreviewed, Where Indexed and Publication Fees. After weighing the scales shown by the adopted subjective and objective measurement tools, Arshad concludes that "From the study conducted, there is a concern regarding limited quantity and quality of globally reputable publication avenues in the discipline of Islamic Economics" (p. 106).

Below are our specific comments on Nienhaus' four bullet points that serve as reasons for the marginal consideration of Islamic works by mainstream journals:

(i) We agree with Nienhaus that given the religious background and unique faith-related methodology, which allows for the role of the divine scriptures, the conventional economists are not that much inclined to both Islamic economics and Christian economics or any other faith-based economics for that matter. This is perfectly understandable and we may attribute this situation to the influence of secularism. 
The secularization process that emancipates reason and language from metaphysical controls has led to the sole reliance of reason. Unfortunately, "Reason in the modern period has oscillated between the two extremes of logical positivism and radical historicism" (Kalin, 2012, p. 11). With the imposition of these extremes, any reference to the divine texts is deemed substandard to the prevalent standard in economics research.

(ii) Nienhaus laments that Islamic economists have not significantly added to the factual and theoretical knowledge. This, to him, happens because of Islamic economists' address of economic problems that are similar to those identified by conventional economists; and the idealistic character of the Islamic economists' solutions to those economic problems. On the former, we wish to defend Islamic economists. This is because given that the subject matter of the discipline is the same as its conventional counterpart, the economic problems in the applied cases are expected to be the same (Khan, 2015). After all, Islamic economics is economics from the Islamic perspective (Siddiqui, 2011). On the latter, there is a growing number of writings on Islamic economics that echo the standpoint of Nienhaus. Hosseini (1992), Kuran (1995b), Warde (2000), Shams (2004), Siddiqi (2008), Farooq (2011), Shinsuke (2012), Mahomedy, (2013), Khan (2015), Mahyudi (2015a and 2015b) and most recently, Mahyudi (2016) are part of those literature that take a critical stance on the viability of Islamic economists' altruism-based proposals. So, we concur with Nienhaus and blame it on the quite simplistic adoption of "idealistic visions of a rather distant future" (Nienhaus, 2013, p. 190).

(iii) According to Nienhaus, Islamic economics science also fails to do both: challenge long established views with new arguments; and offer new fields for theoretical or practical application. Citing the example of how Islamic economics has not filled the gaps in welfare economics, Nienhaus justifies his point. Generally, this paper agrees with Nienhaus' observation on this matter too. We attribute this to Islamic economics' identity crisis (Zaman, 2012; Mahomedy, 2013; Tahir, 2017; Gattoo \& Gattoo, 2017; and Mahyudi \& Abdul Aziz, 2017). With such ongoing confusion, it is difficult to see how the discipline could make significant progress. Nonetheless, we believe that there is a glimmer of hope.
This is owing to Mahomedy's (2013) own allusion to the encouraging self-admissions by first-generation and second-generation Islamic economists that something has gone wrong with the existing efforts to promote Islamic economics as a scientific enterprise. Muhammad Akram Khan was also on this critical yet positive mode in his 2013 Keynote Address at the First World Congress on Integration and Islamicisation of Acquired Human Knowledge. A revival on efforts to infuse the discipline with a much more scientific feel has already started. Khan (2015) is an appealing piece of work to revisit the subject matter and purpose of Islamic economics inquiry. Meanwhile, Furqani (2012 and 2015) re-examines the questions of ends, means and cardinal virtue for the discipline.

Our sense of optimism also comes from the publication of Mahyudi (2015a), Mahyudi (2016), and Mahyudi and Abdul Aziz (2017). These three works deserve a special mention because they strictly construct their discussions on the micro-foundational issue of the economic agent. Bear in mind that, apart from being a fundamental topic in economics, Davis (2009) avows that in addition to markets and values, individuals or economic agents are perennial issues in the philosophy of economics. In brief, those papers argue that in order for the science to be closer to reality, both homo economicus and homo Islamicus must be abandoned by all scholars of economics. Instead, a fresh alternative concept called the 'Universal Man' is proposed. Appreciating the position of the homo economicus presumption and its extensive implications to economics theory-building exercise, this approach of replacing the economic agent is pivotal in developing the building blocks of a proper normal science (Arif, 1985a and 1985b). Furthermore, by taking a more epistemological and universal stance than previous versions, Mahyudi and Abdul Aziz (2017) offer a novel definition for Islamic economics and that is, "the application of the Qur'anic framework in the study of any individual's and society's effort in welfare improvement' (p. 238). This definition's reference to the Qur'ānic framework, which also emphasizes the role of reason without neglecting the hadith, is expected to open up a wider room for the creative mind to roam and to see the urgency for introducing practical solutions to present-day problems. Taking into account this latest 
perspective, there are promising signs for Islamic economics to usher in new offerings to theoretical and practical applications.

(iv) On the irrelevance of Islamic economics for non-Muslims, Nienhaus states that this situation happens because of the old orientation subscribed by the proponents of this nascent discipline. This paper avers that this is the adverse effect from people accepting those Islamic economics definitions that identify this science as a study on Muslims, Muslimmajority countries and people imbued with Islamic values only. However, we believe that change is on the horizon. Notice that the definition quoted in the previous paragraph clearly assigns the whole of mankind, at both the individual and collective levels of existence, as the right audience for Islamic economics. Khan (2013), Siddiqi (2014), Khan (2015) and Mahyudi (2016) also stress on the need for a more universal outlook for Islamic economics science. In other words, while we agree with Nienhaus, we are confident of positive developments in the near future when more and more interested parties, especially policy makers, value the universal appeal embedded in that fresh definition of Islamic economics.

Considering the most recent works reported above, this paper opines that Nienhaus' expressed concern about the lack of interest among the larger intellectual community is only valid at the time he wrote his paper. The third-generation of Islamic economists seems to be indicating some serious commitment to establish Islamic economics as a scientific endeavor that respects both; better coherence with reason and improved relevance to contemporary settings. With the right streamlining of strategies, this expected progress can take place in tune with the increasing interest in Islamic banking and finance among Western academic institutions.

\subsection{Normative Dimensions of Islamic Economics is not a Deterrent Element}

It is wrong to classify Islamic economics in such outright manner as Nienhaus. The first sentence of his subsection 4.2 reads, "Islamic economics is by its own definition normative economics" (p. 191). In comparison, Mannan (1983) avows that the distinction between positive and normative economics is unimportant for Islamic economics. According to Mannan, due to the inseparable links between norma- tive and positive aspects in Islamic economics theory-building and policy formulation steps, "it is neither a positive nor a normative science" (p. 45). But when we accept Mannan's position, it does not mean that we reject the differentiation made between positive and normative economics. Of course, we have to fully acknowledge that the former studies economic problems as they are; whereas, the latter concerns itself with what ought to be. It is just that any attempt to identify Islamic economics as either positive or normative science could be misleading and counter-productive for the sole reason regarding the true nature of Islamic economics provided by Mannan above. The implication here is that to compartmentalize Islamic economics to the normative side is quite simplistic, to say the least. So, any thought of treating Islamic economics as a strictly positive science would face the same fate as well. Thus, this paper concurs with Mannan that Islamic economics deserves to be considered as an integrated social science instead.

As a unique integrated science, it is a consensus among its promoters and critiques that Islamic economics is an ethical-based or value-laden study of individuals and societies. Commenting on the future direction of economics, Mahyudi (2016) avers that Islamic economics sits comfortably in the ongoing action to replace Robbin's fact/value dichotomy with Putnam's (2012) entanglement of fact and value notion that is observable within the discipline of economics as an aftermath of the Great Recession of $2007 / 2008$. Surprisingly, the notion that is proposed by Putnam resonates with that of Heilbroner and Thurow (1975) who, three decades before Putnam, affirmed that "value judgement of one sort or another lies at the basis of all the premises of economic reasoning" (p. 77).

It can be further argued that the more conscious efforts are made to enmesh ethics with the affairs of any scientific discipline, the more intricate the entanglement of fact and value becomes. This situation has been reflective of Islamic economics theory and practice development since its inception in the 1970s under the 'Islamization of Knowledge' intellectual movement that Hashim and Rossidy (2009) aptly label as the 'epistemological revolution' of Muslim scholars and activists. Therefore, it is ardently posited again that the fact that this nascent science is a value- 
based endeavor should not mislead anyone to conclude that Islamic economics is entirely normative in nature. This is because of the increasing realization that economics as a science itself has never been and will never be verily value-free. Hence, we are explicitly contending with Nienhaus' stand as captured in the title for subsection 4.2 of his paper. To establish this contrasting view of ours, we make further elaborations on our Islamic economics definition, 'Qur'ānic framework', Islamic epistemology and Islamic criteria.

\subsubsection{Islamic Epistemology and Islamic Criteria}

As a precursor to our contention, we first clarify in detail our position on Islamic epistemology. To Nienhaus, Islamic economics' distinctive reliance on the primary sources of Qur'ān and Sunnah is the underlying reason why this discipline should be treated as a normative enterprise. In these sources, assertions about good and bad are aplenty while exact cause-effect relations are not expounded. The confusion over the case of rib $\bar{a}$ and interest serves as the only one example to justify his rather weakly supported position. Notice that the central premise of his view is directly associated with the issue of epistemology. This is evident from the following excerpt that also encapsulates Nienhaus' criterion for the 'Islamic' status,

The sources provide only few directly applicable instructions (for example precise rules for heritage) but mostly general principles and normative orientations to guide people in this world. But the interpretation and application of normative Qur'ānic injunctions requires also the use of the 'positive' knowledge at hand. The need to take guidance from that primary sources constitutes the normative and Islamic component, the application of the knowledge of the time is the economics component in 'Islamic economics'. [emphasis in original] (p. 192)

Before we proceed, one important matter must be pointed out in connection to the positive or normative nature of the discipline. As validly argued earlier, Islamic economics is an integrated science. It is our opinion that the whole message from the above quotation is actually a lucid explanation of this integrated science. In fact, the second sentence is a legitimate instruction for the normative and positive elements of such a science to be creatively and effectively blended together for the advancement of
Islamic economics. So, Nienhaus seems to contradict with his own stance summarized in the first sentence of his subsection 4.2 cited earlier. Now, Nienhaus does see it necessary for the positive and normative aspects to intermingle in order to manifest the true substance and character of Islamic economics. Therefore, this paper's assertion that Islamic economics is indeed an integrated science carries more weight than any other position that strictly identifies the discipline as either normative science like Nienhaus; or positive science like Khan (2013).

On this topic of epistemology, Nienhaus is right to view this point as the most distinctive feature for Islamic economics. Haneef (1997) affirms that "The central point of departure of Islamic epistemology from that of the west is in the prominence and centrality of revelation in the pursuit of knowledge" [emphasis in original] (p. 48). To qualify further, Haneef's allusion to the Western epistemological standpoint there relates to the situation ascribed to the dominant secular scientific community of the West that subscribes to the logical positivism standard of truth (Fox, 1997). However, the distinguishing criterion identified by Haneef does little to set apart Rosser and Rosser's (2004) New Traditional Economy that collectively represents Jewish, Buddhist, Confucian, Hindu, Christian and Islamic economics. This is because, by default, reference to the specific divine or main religious text adopted by each religious teaching would be the unequivocal criterion for each different type of the New Traditional Economy or faith-based economics. Consequently, by giving due prominence and centrality to the respective religious texts as the right epistemological stance, each faith-based economics could automatically depart from all secular-based economics and simultaneously, could preserve its own individual uniqueness.

With this correct understanding, this paper is adamant that Haneef's statement must be made more precise by replacing the word 'revelation' with the word 'Qur'ān'. As a result, Islamic economics would be genuinely unique since it is the sole discipline within the diverse mainstream and heterodox schools of economic thought that utilizes the Qur'ân to shape and dictate the evolution of its science. It is this unmistakable quality that prompts Mahyudi and Abdul Aziz (2017) to insert the phrase 'Qur'ānic 
framework' in their definition of Islamic economics. In other words, Islamic economists should, without any hesitation whatsoever, embrace the fundamental idea that Islamic economics is distinct due to its special brand of epistemology; a point that Nienhaus seems to hint at also.

Nonetheless, we beg to differ with Nienhaus on his rather narrow epistemological standard applied to identify ideas and propositions as 'Islamic' or not. Here, we need to explicate the channels of knowledge in Islamic epistemology. Interestingly, that definition places the epistemological stance at the heart of the discipline. While the above paragraph sheds light on both the authentic and unique characters of this relatively young discipline, it is also necessary to deliberate upon another intended purpose behind the use of the 'Qur'ānic framework' phrase; a task undertaken below.

By and large, the term 'Qur'ānic framework' depicts the influence of the channels of knowledge in Islam. Due to the spread of Sharîah-compliant Islamic banking and finance, it is fast-becoming common knowledge that the objects that act as channels are primary sources, senses and 'aql (intellect) (al-Attas, 1989; Haneef, 1997; al-Ghazali, 2005; and Ismail, 2016). According to Haneef (1997, p. 60), this classification is in line with the tradition of past scholars such as al-Ghazali and Ibn Arabi. Similar to the Islamic law experts' treatment of the primary sources, Islamic economists must acknowledge that the Qur'ān and Sunnah are inseparable because one could not function without the other (Kizilkaya, 2015, p. 4). On the relationship between channels, Shahran (2008, p. 13) verifies that Fakhr al-Din alRazi, Ibn al-Jawzi and Ibn Rushd did hold the view that ' $a q l$ and the primary sources must have a symbiotic relationship to enable human beings to correctly assess truth claims. Most importantly, Ismail (2016, p. 7) further explains that all three channels are in harmony with the tenets of Islam based on the prevalent view found in classical works on 'aqidah (Islamic creed). This general overview tersely represents the objects in Islamic channel of knowledge that is to be understood from the phrase 'Qur'ānic framework'.
Naturally, this standpoint does not deny the worthiness of information gathered from the five senses of man and from his exploits on his faculty of reason. In fact, al-Attas (1989), Ismail (2016), Shahran (2008) and Altaie (2016) aver that the Qur'ān itself strongly promotes the use of this Godgiven intellect in man's pursuit to understand, describe and improve the current state of affairs as guided by the ultimate aim of being closer to Allah. This position can be supported by, among others, the following Qur'ānic verses:

We have made clear to you the signs if you shall use your reason. (Qur'ān, 3:118)

And they will say: Had we but listened or used our intelligence, we would not have been among the dwellers of the blazing fire! (Qur'ān, 67:10)

With this kind of perspective, all three identified channels could and should easily be subsumed under the 'Qur'ānic framework'. Thus, this succinct explanation on the 'Qur'ānic framework' serves to show that it is more suitable than Nienhaus' channel of knowledge that becomes the source in determining the Islamic component; whereby in his case, that channel is limited to the primary sources only.

As an extended discussion, we wish to highlight the implications of the 'Qur'ānic framework' in connection with the Islamization of Knowledge (IoK) agenda. Since this Qur'ānic framework goes in tandem with the Islamic worldview, this paper asserts that it may be applied as a criterion in ascertaining 'Islamicity'. Notably, this assertion does not contradict the criterion espoused by Acikgenc (1996) whereby:

That idea, doctrine, disposition, behavior, or discip-
line (in the sense of science) is Islamic, only if it is
developed out of or proceeds directly out of the
Islamic worldview which is inclusive of various
interpretations as well within its own context.
[emphasis in original] (p. 8)

Here, we wish to properly establish the link between the 'Qur'ānic framework' and the use of 'aql viz. role of reason. On this attempt, this paper is inspired by Imam al-Ghazali's two necessary and sufficient 
criteria for the 'Islamic' status. When he evaluates Greek philosophy and its influence on Islamic thought, he critically remarks (al-Ghazali, 2005, p. 30),

Suppose, however, that the statements are found only in the philosophers' books. If they are reasonable in themselves and supported by proof, and if they do not contradict the Book and the Sunnah (the example of Muhammad), then it is not necessary to abstain from using them. [emphasis added] (p. 30)

In the above quotation, Imam al-Ghazali (2005) outlines a straightforward two-tier screening process applicable for all kinds of propositions that spring out entirely from the 'aql channel; that is, neither from the senses nor revelation. To him, the conditions for rejection or acceptance of any pure product of one's mind are two: first, evidence-backed reasoning (i.e. logically sound with supporting proof); and second, not contradicting primary sources. Failure to pass through the first screen implies that any idea or proposition under evaluation is rejected; hence, does not qualify to carry the Islamic status. But, when an idea passes through the first screen, it must then be evaluated at the second tier of screening. So, the Islamic status would only be granted to each idea that is cleared at both levels of screening. Therefore, any idea that is against the primary sources would never attain the Islamic status even though there is ample evidence to support that idea. Historically, this screening process was successfully tested by al-Ghazali as it guided him in writing the highly acclaimed book entitled 'The Incoherence of the Philosophers'.

This two-step filtering process is very beneficial in the context of Islamization efforts; Islamizing economics included. Given that the bulk of existing contemporary human acquired knowledge is tainted by secularism, the two-tier screening process would operationally guide the 'Islamizers' on how to accept or reject presently available assumptions, axioms, theories, models and policies. The extant Western knowledge must be put through that simple yet robust screening process. Once those inherited substantive and methodological knowledge are cleared at both levels of screening, they could obtain the permissible status. Equipped with this basic working of the screening process, we foresee that the 'Qur'ānic framework' has the potential to make the Islamizing economics approach, as opposed to Tahir's (2017) reconstruction approach, to be more practical for the
Islamization of Knowledge agenda. In short, the interaction between conventional economics and Islamic economics is made clearer by relying on the filtering process. Consequently, a huge chunk of the Islamization endeavors could move faster than its current speed of progress.

\subsubsection{Critical Comments on Nienhaus' Section 4.2}

We start this subsection by examining the quality of Nienhaus' single example of riba and interest. Specifically, his allusion is to the confusion about whether rib̄ $\bar{a}$ means usurious practices only (i.e. usury-rib $\bar{a}$ view) or to include any level and type of interest (i.e. interest-rib $\bar{a}$ view). However, we believe that the high rate of growth that the Islamic banking and finance industry has been experiencing worldwide indicates that the controversy has recently ended. Shinsuke (2012) objectively reports that the usury-rib $\bar{a}$ view has been trampled upon by the interest-rib $\bar{a}$ view. This situation reflects that the overwhelming majority of market participants have willingly and consciously adopted the position that rib $\bar{a}$ implicates everything that is connected with the interest rate regardless of its size. With this stronger argument, perhaps Nienhaus may want to provide a different example to effectively prove his point; should he wish to still defend his position.

Next, we respond to Nienhaus' three bullet points that he uses to explain why the Islamic and normative component of Islamic economics is an impediment for non-Muslim economists to engage with Muslim economists. For all three points, the premise of his arguments rests upon his restrictive 'Islamic' criterion. Based on our extensive deliberation on Islamic epistemology, this premise must be augmented to cover the much-wider scope of and role for the Qur'ānic framework. In the absence of this modification, following the standard conditions for deductive arguments, all conclusions that stem from the existing premise are logically unsound even though the conclusions themselves are true statements in their own right. Despite this possible status of Nienhaus' points, we will continue to comment on them since we believe that, acknowledging the highquality contributions of Nienhaus to Islamic economics so far, there are bound to be some valuable lessons for proponents of this discipline. Our comments are as follows: 
(i) We concur with Nienhaus that Islamic economics does have the potential to accelerate its rate of progress by engaging positively with those heterodox economists who share the desire to see a greater room for ethical and moral concerns in every stage of activity carried out by economists. Taking cognizant of Putnam's vision for the future of economics science, we project that many among the mainstream economists would be keen to partake in this engagement effort sooner than previously expected.

(ii) We are also in agreement with Nienhaus on this second point; that is the ambiguity surrounding the added value that Islamic epistemology could offer. In defense of Islamic economics, its proponents require more time to adapt to the rigor of scientific thinking. Mahyudi (2016), for instance, is perhaps a small step in the right direction. Motivated by how unrealistic is the homo economicus presumption in neoclassical economics theory-building stages, he fairly observes that Islamic economics is actually guilty of the same kind with its unrealistic homo Islamicus. So as to be closer to reality, Mahyudi and Abdul Aziz (2017) proposes the 'Universal Man' to replace both concepts of economic agents. This replacement would arguably enhance the context validity quality of economic theories and analyses. In a way, we now put forth that this 'Universal Man' is one notable example of how the Qur'ānic framework could improve the existing micro-foundations of the economics discipline. Thus, the potential for further refinements that are inspired by the adoption of the Qur'ānic framework is not to be denied.

(iii) By placing the common objective of wellbeing, we definitely agree with Nienhaus on the critical need for more and more Islamic economists to have meaningful and intellectually promising dialogue with all other interested parties regardless of their race and faith. If this reminder is not taken up seriously, Islamic economists would then miss out on global-scale efforts such as The World Economic Forum whose mission is, among others, to promote moral and intellectual integrity in economic pursuits of states and societies. In fact, this paper highlights that this kind of clamor has also been voiced out recently by some Muslim economists like Khan (2013) and Khan (2015), to name a few. With this piece of observation, the future looks bright; an attractive outlook that even Tahir (2017), who calls for a reconstruction of Islamic economics rather than Islamization of economics, predicts too.

\subsubsection{Subsection Summary}

In a nutshell, this subsection attempts to display how Islamic economics' normative dimensions are not an impediment to its progress. The huge and vital role of the intellect is somewhat forgotten or at least marginalized in the typical legal-oriented Islamic discourse. This could be the reason why non-Muslims and some Muslims alike tend to construct their supporting views and critiques based on their incomplete understanding on Islamic epistemology. The use of the more comprehensive yet practical standard, expressed as the 'Qur'ānic framework' should be seen as one that addresses Bakar's (2016) stern reminder when he says, "Islam always stresses the importance of a valid epistemology in building up any theory of knowledge" (p. 259). This paper has deliberated at length to emphasize that the Qur'ānic framework does provide a truly distinct vantage point for the development of the discipline's ontology, epistemology and axiology. Hence, we are confident that this line of progress would bring about the universallydesired changes to Islamic economics science; especially the ones that we find agreement with Nienhaus.

\section{3 "IE Light" Studies}

Nienhaus starts subsection 4.3 by making a bold statement: "However, most contributions in this field (i.e. Islamic finance) are not debates on IE issues" [parentheses added] (p. 193). He uses the example of non-Muslims utilizing some basic knowledge on a particular segment of Islamic economics such as the prevalent-maxims to write on Islamic finance. Meanwhile, Muslims scholars who analyze the technical and sectorial topics in Islamic finance form another kind of works on Islamic finance. Unfortunately, he rightly observes that contributions of these types lack that systemic dimension that is always promoted by Islamic economists. Based on this reference to the specific character of the existing writings by both the non-Muslim and Muslim authors, one can safely say that the premise for that statement is his categorization of Islamic economics publications into 'IE light studies' and 'IE proper'.

One can understand our previous point better once we provide clarity over the difference between 'IE light' and 'IE proper' studies. Nienhaus considers 
those studies done on topics with relevance for Islamic economics in a conventional framework, including writings on Islamic finance as described above, as 'IE light' studies. He contrasts this kind of studies with that of 'IE proper'. We gather from the first paragraph on page 194 that what he means by 'IE proper' studies are those academic works that incorporate either a normative content or a systemic perspective. The entire subsection 4.3 of his paper is dedicated to delineate on the implications of this categorization.

On the reasoning of consistency of arguments, the above two paragraphs have in effect demonstrated the contradiction of Nienhaus. On one hand, Nienhaus asserts "If a normative content or a systemic perspective is constitutive for a contribution to IE, most papers of the indicated type do not qualify as such, although they have 'Islamic' in their title" (p. 194). So, 'IE proper' seems to be the only type of writings that can be considered as part of Islamic economics literature. On the other hand, this normative or systemic criteria are purposely adopted as the practical basis for Nienhaus to identify works on 'IE proper' and separate them from 'IE light' ones.

Notice that Nienhaus still maintains the adjective 'Islamic economics' in order to differentiate 'Islamic Economics proper' against 'Islamic Economics light' studies. This serves to show that any writings that can fall under either one of those two categories would still be classified as writings on Islamic economics by Nienhaus himself. In other words, regardless of the category that an academic publication finds itself to be placed under, it is still treated as a worthy contribution to the Islamic economics body of knowledge.

The question now is: How can we reconcile this contradiction? We can easily do this by treating the two categories to display the different levels of Islamic content instead. This would allow 'IE light' studies not to lose its 'Islamic' identity. After all, the categories differ primarily in terms of the topic and approach undertaken by the respective authors. Furthermore, both categories are of course Islamic worldview-consistent; hence, they are more than eligible to carry the Islamic status (Acikgenc, 1996). Simultaneously, our proposed reconciliation method would show 'IE proper' studies to contain higher Islamic content than that of 'IE light' output. So, if
Nienhaus' classification has a practical value, this paper is of the view that it is more suitable to change the phrase 'IE proper' to 'IE heavy' term so as to portray the different degrees of contribution within each Islamic economist's scholarly output better.

Equipped with this understanding, we can actually explain one correct observation of Nienhaus. Nienhaus rightly realizes that there is an increasing number of 'IE light' published papers and its growth is much faster than 'IE heavy' ones. Owing to the arduous nature of presenting commendable normative and systemic-oriented ideas in scientific journals, it is palatable for us to state that that observation is definitely true. That orientation itself attracts a small number of contributors among Islamic economists; a scenario that is perhaps similar to esoteric fields of study such as philosophy of science and mathematical science. Therefore, this particular observation is worth noting to aid in future assessment on the discipline's progress.

About the advantages for authors of 'IE light' studies, we totally concur with Nienhaus' penetrative insights. Interestingly, Khan (2013) avers that it is imperative for Islamic economics to get the attention of the wider intellectual community and appeal to not only Muslims. These advantages do provide some sense of motivation for more people; regardless of their religion, race and nationalities, to work on Islamic economics even though they know that their level of contribution is not up to the level of 'IE heavy'. It is also not a surprise if these advantages may entice more brilliant and creative minds into the fold of Islamic economics. Thus, as mentioned by Nienhaus, these advantages could be highly rewarding given that the discipline is still in its infant stage of development albeit four decades of progress.

All in all, we posit that this paper has managed to show a major weakness in Nienhaus' premise of arguments applied in his subsection 4.3 and by doing so, this paper has exposed the unsound nature of the ensuing conclusions. Other than those explicitly stated disagreements, we truly appreciate the detailed and objective points raised by Nienhaus especially on the need for 'IE heavy' studies to venture into under-researched areas, for example, methodology of Islamic economics; a crucial point that is also stressed upon by Haneef (2005) and Haneef and Furqani (2011). 


\subsection{Islamic Economics as Political Economy}

According to Nienhaus, the systemic dimension; which gives a critical and action-oriented trait to the polemics in Islamic economics, has the implication of turning Islamic economics into political economy. Up until now, the bulk of 'IE heavy' discussions tend to focus on the design of the ideal world with little formula given to effectively attain those ideals. To us, this line of critique is most fair since it merely echoes the earlier chorus of critics directed towards Islamic economics (Kuran, 1983, 1995a and 1995b; Mills \& Presley, 1999; Warde, 2000; Shams, 2004; Farooq, 2011; and Mahomedy, 2013). So, we perfectly understand why Nienhaus sees Islamic economics as political economy.

In his subsection 4.4, Nienhaus identifies three deficits in this discourse. Below are our critical comments on them:

(i) It is most agreeable that the set of ideals is one that is complex and multidimensional. Nienhaus highlights that the existing proposals of the Islamic economic system range from "variants of a socially moderated market economy to quite authoritarian models of a welfare dictatorship" (p. 196). It is interesting to note that Mahomedy (2013) also presents a similar finding based on his very commendable review on Islamic economics literature. Here, this paper has to mention also Mahomedy's criticism on the absence of discussion between the diverging views amongst Islamic economists. And of course, as rightly pointed out by Nienhaus, those who are outside of Islamic economic institutions could partake in this discussion by providing constructive feedbacks on the coherence and consistency of all proffered ideas and concepts. Our rationale to this welcoming remark is our adoption of the 'Qur'ānic framework' as the distinct character of Islamic epistemology. On the accounts that coherence and consistency are desired qualities of logic, which is an intractable use of man's 'aql, they are necessarily crucial to evaluate any kind of proposition from both conventional and Islamic economics alike. Nonetheless, one must always keep in mind that all ideas, regardless of who the idea-champion is, must pass through the two screening criteria advocated by al-Ghazali (2005) as explicated earlier in subsection 2.2. Only then can those ideas obtain entry into the Islamic economics body of knowledge. We are adamant that this nature of epistemology for Islamic economics would open doors for more creative contributions that support the IoK agenda not only from bright-minded Muslims; but also non-Muslims. Hence, the concern of Khan (2013) and Khan (2015), as also stated earlier, is well taken care of.

(ii) On Nienhaus' complaint about the inability of Islamic economics to establish a convincing theory of transition, we share his views. In fact, Mahyudi (2015b) is a very recent attempt to specifically address this complaint by demonstrating how a Sharī'ahbased public policy would enable an Islamic economy to experience the transition from the present reality to the ideal system. Published works, like Mahyudi (2015b), are necessary in order to reignite the hitherto comatose discussion on the Islamic economic system; thus, allaying Siddiqi's (2008) fear of losing that grand idea of Islamic economics. Islamic economics must also thank Nienhaus for his tips on how to advance forward with this matter. According to Nienhaus, proponents of the discipline should not ignore the extensive amount of literature on systemic change or persistence since they offer priceless take away lessons for Islamic economics based on the evidence of post-communist countries in Central Asia and Central and Eastern Europe. This advice deserves a special mention because of the novelty of this idea.

(iii) Notably, another agreed upon deficiency is the study of the evolution of ideal systems such as the German Social Market Economy and the Scandinavian welfare states. These examples do have "striking similarities with 'mainstream' models of an Islamic economic system" [emphasis added] (p. 197) that qualify them to be 'field experiments' that offer real-world examples for the Islamic political economy to have a better grounding. Here, we wish to comment further on the 'striking similarities' observation. Amazingly, Kizilkaya (2015) and Khan (2015) present the justification for such similarities. Kizilkaya explains:

As people engage in various kinds of commercial relations that have been similar for the most part across all geographies and periods, it would not be accurate to claim that their (i.e. the different economic systems) difference lies in their functions. [emphasis and parentheses added] (p. 5) 
This resemblance is natural and expected given that their subject matter is the same (Khan, 2015). Khan clarifies that "The real difference will lie in the details" (p. 15) and these details include the institutional framework and meaning of wellbeing concept. This honest admission is vital as it adds weight to Nienhaus' guidance for Islamic political economy to learn from the present challenges in those cited countries.

Finally, we concur with Nienhaus that the end game for the Islamic political economy is practical solutions to economic woes of the population. To that end, 'IE light' research should fill up the gaps left by 'IE proper' studies especially on the critical topic of economic development and wealth distribution. Thus, this paper avers that this complementary nature of existence for 'IE heavy' and 'IE light' works is the best recipe for a harmonious relationship among proponents of Islamic economics.

\section{The Unsettled Relationship between Islamic Economists and Sharī'ah Scholars: An Amicable Way Forward}

Nienhaus identifies another noticeable tension along Islamic economics' progress. This refers to the tug of war between Islamic economists and Sharī'ah scholars or jurists on the path of that progress. It is noted that the battleground is primarily in the Islamic banking and finance industry. Presently, the Shari'ah scholars are on the side of the bankers and shareholders due to pragmatic reasons (Mahyudi, 2016). This is unavoidable because of the different expectations that one group of experts has against the other. Bakar (2016) openly declares that "The Sharī'ah scholars' main task is to verify whether a particular contract or a term or a condition in any financing arrangements is in line with the Sharīah" (p. 48); and when alternative proposals or products or options are all found to be Sharī'ah-compliant, "The Sharī'ah board cannot force the Islamic financial institution to adopt a particular contract, while sidelining other contracts" (p. 49). This is because if any of the Sharī ah board member ever does so, he or she is acting beyond the given mandate stipulated in the terms of reference of his or her appointment. This limited scope of the role and function for the Sharīah experts in the practice of Islamic finance tends to have adverse implications on the attainment of Islamic economics objectives (Mohammad \& Shahwan, 2013). This inadvertent effect on the social and ethical objectives of Islamic economics is the source of the Islamic economists' dissension. But, this paper asserts that we must be fair to the Sharī'ah experts too here.

To improve the status quo, the presence of this uncomfortable feeling between Sharī'ah scholars and Islamic economists must not be disputed. In fact, Bakar (2016) makes recurring attempts in his book 'Shariah Minds in Islamic Finance' to address this unwanted situation. With our aim to appease this unpleasant scenario, we believe that Islamic economists should take heed on some pertinent advice furnished by Bakar, who is one of the most prominent Sharī'ah scholars in the global financial industry. Below, we list out some of Bakar's remarks that are to be taken positively by Muslim economists:

... I could not help but notice some imperfections in the thought processes of Muslim economists when making these conclusions (if not insinuations). The reason, I believe, is that the fundamental assumptions that form the basis of the Muslim economists' perceptions are flawed and unfounded from a technical Shariah viewpoint. [emphasis added] (p. 183)

... some of Muslim economists are not well exposed to data analytic skills. (p. 186)

... some Muslim economists have been too obsessed with broad policies and data mining, without coming out with a concrete plan of action; one which is executable without much restrictions. (p. 186)

Can our Muslim economists rethink on the best approach to contribute to Islamic finance, instead of focusing on Shari'ah value-driven comments and perspectives? (p. 186)

Thus, the time has come for these Muslim economists to rewrite some of their books, taking into account the new regulatory policies and hard data... (p. 258)

Muslim economists should seriously start considering enhancing their knowledge of both the technicalities of Islamic legal theory and maqāssid al-Shari ah to make their efforts to discover the great theories of Islamic economics perfect. [emphasis added] (p. 264) 
The above excerpts seem to indicate that Islamic economists have encroached on the area of Islamic jurisprudence in formulating and articulating their ideas. At this juncture, perhaps it is best to refresh ourselves with Zarqa's (2003) words of guidance:

The main difference between the science of jurisprudence and Islamic economics is that the basic objective of jurisprudence is to arrive at normative statements, which are legal judgements or rulings... On the other hand, the objective of Islamic economics (as well as conventional economics) is to arrive at descriptive hypotheses or assumptions that diagnose reality and link the various economic phenomena. (p. 22)

While Zarqa is referring to the purpose of inquiry, Saleem (2010) avers that since the purpose of inquiry in the two disciplines are different, their methods and unit of analysis are bound to be different as well. Furthermore, we should be worried about one repercussion from the existing encroachment. Khan (2015) expresses this worry as he notices that one factor that unintentionally causes Islamic economics to show a lack of vision about its methodology is the undue obsession with Islamic jurisprudence by Islamic economists. Therefore, we strongly recommend that for the sake of smoother future development, protagonists in both fields of study must show more respect to the boundary of each discipline.

\subsection{Law without Economics: Form over Substance}

The main thrust of Nienhaus' argument lies in the inability for proper economic thinking to have its footing among the scholars of the Sharīah. On this vital issue, which has moved from bad to worse with the advent of creative adaptation of Islamic legal doctrines in commercial practices for the Islamic banking and finance industry, we opine that Nienhaus has indeed exposed some alarming concerns. So, here, we wish to add several pertinent points to ponder.

The undeniable fact is that Sharī ah experts have a different training regime than economists or any other social scientists, for that matter. They have been groomed to suit with the specific purpose and orientation of arriving at a particular legal position on a very specific action or situation (Saleem, 2010). By 'specific', we also mean 'narrowly defined'. This is a trait that is most crucial for the jurists to come out with the most exact legal, not ethical, position on the referred case. Apparently, this is not how we prepare budding economists.

One legitimate concern mentioned by Nienhaus is the practical manifestation of the maslahah and maqāșid al-Sharīah in contemporary times. The present practice in the financial markets is to depend on the appointed Shari'ah experts' interpretations. However, this is competently argued to be insufficient owing to the necessity of a systemic approach in that exercise of interpreting. Meanwhile, this systemic approach is part ingredient of how to produce an economics graduate. Equally important is that the graduate has been exposed to analytical knowledge for him or her to predict the systemic implications that could arise from one Sharī ah board's decision. Of course, it is too much of an asking if we demand the Sharī'ah experts to take economic courses before they hold a seat in Shari'ah committees of banks and other financial institutions. Thus, one practical improvement to inject substance to the legal form of the Islamic banking and finance industry's offerings is by ensuring that all Sharīah committees must be represented by both Islamic law and economics experts.

\subsection{Sharī'ah-compliant Structured Finance after the Financial Crisis}

The recent global crisis has laid bare the intricate yet pernicious consequences of the conventional financial system. Consequently, any future development within the finance industry as a whole that does not take a detour from the conventional system's way is a journey on the road to perdition. Thus, it is quite incomprehensible for any Islamic scholar to argue that the cause of public interest is best promoted when the Islamic banking and finance system mimics that of the conventional one. The crisis actually compels the Islamic finance industry to be more authentic, while maintaining at least the same level of pragmatic value, in their product development and marketing strategies. This is the real test for Islamic finance practitioners. Admittedly, this call is not a legalistic justification for Islamic finance to do some tweaking on how it manages itself. It is just an ethical justification; one that would direct Islamic finance to do a great service not just in Muslim countries, but also non-Muslim lands. 


\section{Concluding Remarks}

Avid observers may notice that the 'Islamization of Knowledge' epistemological revolution is, at present, in a state of impasse. Nonetheless, this situation is not that obvious in Islamic economics because of the vast market interest in Islamic finance worldwide. However, this preoccupation amongst Islamic economists within the narrow confines of Islamic finance would not significantly aid in developing Islamic economics as a science that fits into Kuhn's (1970) description of normal sciences. The technical and applied nature of Islamic finance research would inevitably push aside the more fundamental topics from being attended to by the active participants of Islamic economics discourses.

This paper clarifies some foundational matters on substance and method of Islamic economics. To that end, we have injected an air of freshness to our many points of agreement and disagreement with Nienhaus by bringing into attention a sizeable number of academic works that have been published in the last five years. By doing so, we have deliberated at length on the new definition for Islamic economics suggested by Mahyudi and Abdul Aziz (2017) and the implications of the 'Qur'ānic framework' on Islamic epistemology and Islamic criteria. This deliberation, in particular, has allowed us to proffer novel insights that could inspire better engagement between Islamic economists with both conventional economists and Islamic law experts. Finally, we assert that only by empowering future generations of Islamic economists with enhanced intellectual clarity and integrity can Islamic economics progress as a proper scientific discipline housing solid theories and practical policies that are coherent, consistent, and comprehensive. 


\section{References}

Acikgenc, Alparslan (1996). Islamic Science: Towards a Definition. Kuala Lumpur, Malaysia: International Institute of Islamic Thought and Civilization.

Altaie, Basil (2016). God, Nature and the Cause: Essays on Islam and Science. Abu Dhabi, UAE: Kalam Research \& Media.

Arif, M. (1985a). Toward a Definition of Islamic Economics: Some Scientific Considerations. Journal of Research in Islamic Economics, 2(2), 79-93.

Arif, M. (1985b). Toward the Shari'ah Paradigm of Islamic Economics: The Beginning of a Scientific Revolution. The American Journal of Islamic Social Sciences, 2(1), 79-99.

Arshad, Mohd. Nahar Mohd. (2016). An Assessment of Journal Quality in the Discipline of Islamic Economics. Islamic Economic Studies, 24(1), 95-114.

al-Attas, Syed Muhammad Naquib (1989). Islam and the Philosophy of Science. Kuala Lumpur, Malaysia: International Institute of Islamic Thought and Civilization.

Aydin, N. (2013). Method and Substance of Islamic Economics: Moving Where? A Comment. Journal of King Abdulaziz University: Islamic Economics, 26(1), 257-267.

Bakar, Mohd. Daud (2016). Shariah Minds in Islamic Finance. Kuala Lumpur, Malaysia: Amanie Media.

Davis, John B. (2009). Competing Conceptions of the Individual in Recent Economics. In D. Ross \& H. Kincaid (Eds.), The Oxford Handbook of Philosophy of Economics (pp. 223-244). Oxford, NY: Oxford University Press.

Farooq, M.O. (2011). Self-interest, Homo Islamicus and Some Behavioral Assumptions in Islamic Economics and Finance. International Journal of Excellence in Islamic Banking and Finance, 1(1), 52-79.

Fox, Glenn (1997). Reason and Reality in the Methodologies of Economics: An Introduction. Cheltenham, UK: Edward Elgar Publishing.

Furqani, Hafas (2012). The Foundations of Islamic Economics: A Philosophical Exploration of the Discipline (Unpublished doctoral dissertation). International Islamic University Malaysia, Kuala Lumpur, Malaysia.

Furqani, Hafas (2015). Individual and society in an Islamic ethical framework: Exploring key terminologies and the micro-foundations of Islamic economics. Humanomics, 31(1), 74-87.

Gattoo, Mujeeb Hussain, \& Gattoo, Muneeb Hussain (2017). Modern Economics and The Islamic Alternative: Disciplinary Evolution and Current Crisis. International Journal of Economics, Management and Accounting, 25(2), 173-203.
al-Ghazali, Muhammad bin Muhammad (2005). Deliverance from Error \& The Beginning of Guidance (W. Montgomery Watt, Trans). Kuala Lumpur, Malaysia: Islamic Book Trust. (Original work published 1842)

Haneef, M.A. (1997). Islam, the Islamic Worldview and the Methodology of Islamic Economics. IIUM Journal of Islamic Economics \& Management, 5(1), 39-65.

Haneef, M.A. (2005). Islamic Economics in the $21^{\text {st }}$ Century: Selected Issues and Future Direction. In M. A. Haneef \& M. Anwar (Eds.), Studies in Islamic Economics in the $21{ }^{\text {st }}$ Century: Shari'ah Foundations, Theory and Institutions (pp. 1-15). Kuala Lumpur: International Islamic University Malaysia.

Haneef, M.A., \& Furqani, Hafas (2011). Methodology of Islamic Economics: Overview of Present State and Future Direction. International Journal of Economics, Management and Accounting, 19(1), 1-26.

Hashim, R. \& Rossidy, I. (2009). A Comparative Analysis of the Conceptions of Al-Attas and Al-Faruqi. In Mohd. Yusof Hussain (Ed.), Islamization of Human Sciences (pp. 115-140). Kuala Lumpur: IIUM Press.

Heilbroner, Robert L., \& Thurow, Lester C. (1975). The Economic Problem. New Jersey, USA: Prentice Hall.

Hosseini, Hamid (1992). From Homo Economicus to Homo Islamicus: The Universality of Economic Science Reconsidered. In Cyrus Bina \& Hamid Zangeneh (Eds.), Modern Capitalism and Islamic Ideology in Iran (pp. 103-117). New York: St. Martin's Press.

Ismail, Mohd. Zaidi (2016). Aqal Dalam Islam: Satu Tinjauan Epistemologi [ ${ }^{A} A q$ in Islam: An Epistemological Overview]. Kuala Lumpur, Malaysia: Institut Kefahaman Islam Malaysia (IKIM).

Kalin, Ibrahim (2012). MABDA English Monograph Series No. 12. Reason and Rationality in the Qur'an. Amman, Jordan: The Royal Aal Al-Bayt Institute for Islamic Thought.

Khan, M.A. (2013, August). Reconstruction of Economics Based on the Paradigm of Tawhid: Present Challenges and Future Prospects. Keynote Address at the First World Congress on Integration and Islamicisation of Acquired Human Knowledge, International Islamic University Malaysia, Kuala Lumpur, Malaysia, 23-25 August, 2013.

Khan, M. Fahim (2015). Revisiting the Foundational Concepts and Thoughts in Islamic Economics: Where Islamic Economics Should Originate in Terms of Theoretical Content. In Taha Egri \& Necmettin Kizilkaya (Eds.), Islamic Economics: Basic Concepts, New Thinking and Future Directions (pp. 12-57). Newcastle upon Tyne, UK: Cambridge Scholars Publishing. 
Kizilkaya, N. (2015). Introduction: Some Considerations on the Methodology of Islamic Economics Studies. In Taha Egri \& Necmettin Kizilkaya (Eds.), Islamic Economics: Basic Concepts, New Thinking and Future Directions (pp. 1-10). Newcastle upon Tyne, UK: Cambridge Scholars Publishing.

Kuhn, T. (1970). The Structure of Scientific Revolutions. Chicago, USA: University of Chicago Press.

Kuran, T. (1983). Behavioral Norms in the Islamic Doctrine of Economics: A Critique. Journal of Economic Behavior \& Organization, 4(4), 353-379.

Kuran, T. (1995b). Islamic Economics and the Islamic Subeconomy. Journal of Economic Perspectives, 9(4), 155-173.

Kuran, T.(1995a). Further Reflections on the Behavioral Norms of Islamic Economics. Journal of Economic Behavior \& Organization, 27(1), 159-163.

Mahomedy, Abdulkader Cassim (2013). Islamic Economics: Still in Search of an Identity. International Journal of Social Economics, 40(6), 556-578.

Mahyudi, M. (2015a). 'True Man': The True Economic Man for Islamic Economics. Global Journal AlThaqafah, 5(2), 63-72.

Mahyudi, M. (2015b). Reviving the Islamic Economic System through Shariah-based Public Policy. Humanomics, 31(4), 415-429.

Mahyudi, M. (2016). Rethinking the Concept of Economic Man and its Relevance to the Future of Islamic Economics. Intellectual Discourse, 24(1), 111-132.

Mahyudi, M., \& Abdul Aziz, Enizahura (2017). Rethinking the Structure of Islamic Economics Science: The Universal Man Imperative. International Journal of Economics, Management and Accounting, 25(2), 227-251.

Mannan, M. A. (1983). Islamic Economics as a Social Science: Some Methodological Issues. Journal of Research in Islamic Economics, 1(1), 41-50.

Mills, P., \& Presley, J. (1999). Islamic Finance: Theory and Practice. Hampshire, UK: Macmillan.

Mohammad, M.O., \& Shahwan, S. (2013). The Objective of Islamic Economic and Islamic Banking in Light of Maqasid Al-shariah: A Critical Review. Middle-East Journal of Scientific Research, 13, 75-84.

Nienhaus, V. (2013). Method and Substance of Islamic Economics: Moving Where? Journal of King Abdulaziz University: Islamic Economics, 26(1), 175-208.
Putnam, H. (2012). For Ethics and Economics without the Dichotomies. In H. Putnam \& V. Walsh (Eds.), The End of Value-free Economics (pp. 111-129). New York, USA: Routledge.

Rosser, J.B., \& Rosser, M.V. (2004). Comparative Economics in a Transforming World Economy (2nd ed.). Massachusetts, USA: The MIT Press.

Saleem, Muhammad Yusuf (2010). Methods and Methodologies in Fiqh and Islamic Economics. Review of Islamic Economics, 14(1), 103-123.

Shahran, Mohd. Farid (2008). Isu-isu Dalam Pemikiran Islam [Issues in Islamic Thought]. Kuala Lumpur, Malaysia: Angkatan Belia Islam Malaysia.

Shams, R. (2004). A Critical Assessment of Islamic Economics (HWWA Discussion Paper No. 281). Hamburg Institute of International Economics, Hamburg. Retrieved from: http://ageconsearch.umn. edu/bitstream/26295/1/dp040281.pdf

Shinsuke, N. (2012). Critical Overview of the History of Islamic Economics: Formation, Transformation, and New Horizons. Asian and African Area Studies, 11(2), 114-136.

Siddiqi, M. N. (2008). Obstacles of Research in Islamic Economics. Journal of King Abdulaziz University: Islamic Economics, 21(2), 81-93.

Siddiqi, M. N. (2014). Islamic Economics: Where from, Where to? Journal of King Abdulaziz University: Islamic Economics, 27(2), 61-71.

Siddiqui, S. A. (2011). Defining Economics and Islamic Economics. Review of Islamic Economics, 15(2), 113142.

Tahir, S. (2017). Islamic Economics and Prospects for Theoretical and Empirical Research. Journal of King Abdulaziz University: Islamic Economics, 30(1), 3-20.

Warde, Ibrahim (2000). Islamic Finance in the Global Economy. Edinburgh, Scotland: Edinburgh University Press.

Zaman, A. (2012). Crisis in Islamic Economics: Diagnosis and Prescriptions. Journal of King Abdulaziz University: Islamic Economics, 25(1), 147-169.

Zarqa, Muhammad Anas (2003). Islamization of Economics: The Concept and Methodology. Journal of King Abdulaziz University: Islamic Economics, 16(1), 3-42. 
Mohd Mahyudi obtained his BSc in Finance and Accounting from the University of Salford, UK (1998); MBA, specializing in Islamic Banking and Finance from the International Islamic University Malaysia (IIUM) (2002); and PhD. Economics from IIUM (2008). In 2008, he joined the Department of Economics as Assistant Professor at the Kulliyyah of Economics and Management Sciences (KENMS), IIUM. He teaches subjects directly related to Islamic economics at both the undergraduate and post-graduate levels; for example, Foundation of Islamic Economics, Issues in Islamic Economics and Islamic Economics Thought. He is also currently overseeing the 'Islamization of Knowledge' efforts at KENMS in his capacity as the Islamization Coordinator. His research interest is mainly on the substance and methodology of Islamic economics and Islamization of knowledge areas. Other than journal articles on topics of epistemology, micro-foundations, philosophy of Islamic economics science and public policy published in Humanomics; Intellectual Discourse; Global Journal AlThaqafah; and International Journal of Economics, Accounting and Management; he co-edited two books entitled 'Zakat and its Poverty Alleviation Goal' in 2015 and 'Islamic Economics Education in Southeast Asian Universities' in 2013.

E-mail:mohdmahyudi@gmail.com

Enizahura Abdul Aziz is currently a Research Fellow at the Centre for the Study of Shari'ah, Law and Politics, Institute of Islamic Understanding Malaysia (IKIM). She obtained her B.A (Hons) in Politics from University of East London, UK; and Masters in Political Science (Specializing in Public Policy \& Public Administration) from International Islamic University Malaysia (IIUM). At present, she is pursuing her $\mathrm{PhD}$ in Political Science at IIUM. She is one of the first batch alumni of the Worldview of Islam Series (WISE) jointly organized by Centre for Advanced Studies on Islam, Science and Civilization (CASIS), Technology University of Malaysia (UTM) and Assembly of Intelectual Muslims (HAKIM). Her areas of interest are development and public policy, national unity, dialogue and politics in Islam. Among her research projects are Development of Malaysia Socio-Religio Harmony Index Instruments, Development of Fiqh Taámul (Inter-Religious Interaction from the Fiqh Dimension). She has edited two books: 'Inter-Religious Dialogue: Guidelines from the Islamic Perspective' and 'Religion, Dialogue \& Peaceful Coexistence' that was published in March 2018. She also writes in local media and present papers at national and international conferences covering topics of national unity, dialogue and politics from the Islamic perspective.

E-mail: enizahura@ikim.gov.my 


\title{
إعادة النظرفي منهجية ومرتكزات الاقتصهاد الإسلامي
}

\author{
محمد ماهيودي \\ أستاذ مساعلد ، كلية الاقتصاد والعلوم الإدارية، ماليزيا الجامعة الإبالامية العالمية \\ انيزهورة عبد العزيز \\ مركز دراسات الشسبعة والقانون والسياسة، المعهد الإسلامي (IKIM) ماليزيا
}

المستخلص. تقدم هذه الورقة رؤى جديدة حول منهجية ومرتكزات الاقتصاد الإسلامي من خلال

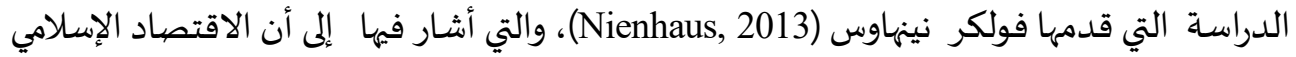
يجهله الكثيرون وعلى نطاق واسع، وأنه غير واضح المعالم، وعلى الرغم من الكتابات الكثيرة فيه إلا

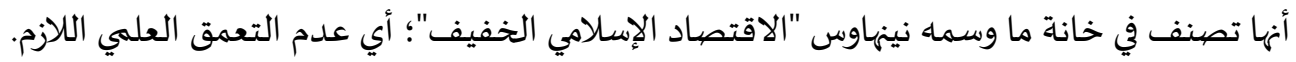

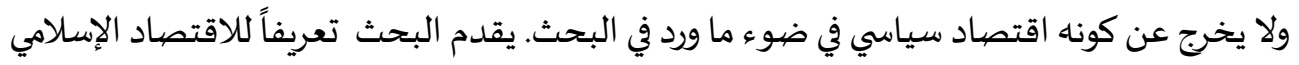

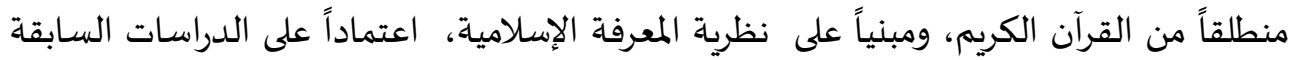

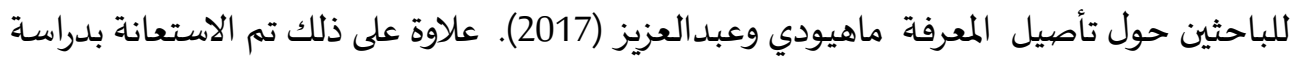

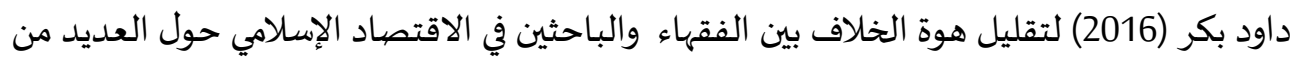
القضايا التشريعية والقانونية والفكرية ومنتجات المالية الإسلامية. كما يقدم البحث وفي ضوء معرفة المؤلفين التامة بفلسفة الاقتصاد الإسلامي بعض المقترحات حول مختلف القضايا لتقريب وجهات النظر بين الفقهاءوالباحثين في الاقتصاد الإسلامي، والخبراء في الاقتصهاد التقليدي . الكلمات الدَّالة: فلسفة الاقتصاد الإسلامي، علم الاجتماع الإسلامي، إسلامية المعرفة، الاقتصاد

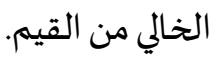
تصنيف B41, B59, A12, A13 :JEL تصنيف KAUJIE 